\title{
Hoof Wall
}

National Cancer Institute

\section{Source}

National Cancer Institute. Hoof Wall. NCI Thesaurus. Code C77626.

The keratinized outer portion of the foot of a horse. 